\title{
Elemental and organic carbon measurements with a two-step heating-gas chromatography system in snow samples from the Tibetan Plateau
}

\author{
Baiqing $\mathrm{XU},{ }^{1,2}$ Tandong $\mathrm{YAO}^{1,2}$ Xianqin $\mathrm{LIU}^{2}$ Ninglian WANG ${ }^{2}$ \\ ${ }^{1}$ Laboratory of Environment and Process on Tibetan Plateau, Institute of Tibetan Plateau Research, \\ Chinese Academy of Sciences, 18 Shuangqing Road, Beijing 100085, China \\ E-mail: baiqing@itpcas.ac.cn \\ ${ }^{2}$ Laboratory of Cryosphere and Environment, Cold and Arid Regions Environmental and Engineering Research Institute, \\ Chinese Academy of Sciences, 260 Donggang West Road, Lanzhou 730000, China
}

\begin{abstract}
In this study, an optimized two-step heating-gas chromatography system is used to measure elemental carbon (EC) and organic carbon (OC) content in snow and ice, with the ability to quantify the elemental and organic carbon species in a snow or ice sample of 60-80 g. In this system, OC and EC are transformed into $\mathrm{CO}_{2}$ in a stream of oxygen at $340^{\circ} \mathrm{C}$ and $650^{\circ} \mathrm{C}$, respectively. The resulting $\mathrm{CO}_{2}$ is accumulated in two molecular-sieve traps, and then put into a gas chromatograph equipped with a flame ionization detector by heating the traps to $200^{\circ} \mathrm{C}$ in a helium stream. Background contamination (mainly caused by impurities in the oxygen stream) and accuracy are dominated by the variability of the blank loads on the pre-cleaned filters, which are $0.50 \pm 0.04(1 \sigma) \mu \mathrm{gC}$ for $\mathrm{OC}$, and $0.38 \pm 0.04(1 \sigma) \mu \mathrm{gC}$ for EC. The system is suitable for snow and ice sample measurements, with the same precision as shown for the blank tests. EC and OC concentrations have been measured in snow samples collected from different glaciers on the Tibetan Plateau. The results allow quantification for the first time of the different carbonaceous particle contents on the Tibetan Plateau and other regions. The concentrations of EC and OC particles in snow show a clearly decreasing trend from east to west and from north to south on the plateau, excluding the Pamirs region. The highest mean EC content, $79.2 \mathrm{ng} \mathrm{g}^{-1}$, was found in the northeast region, and the lowest, $4.3 \mathrm{ng} \mathrm{g}^{-1}$, was found in the western Himalaya. We note that even slight surface melting results in fresh snow getting dirtier, especially in regions with higher pollution such as seen on a glacier in the Qilian Shan. Here, the EC and OC concentrations in the fresh snow average 6.6 and $87.5 \mathrm{ngg}^{-1}$, but after 2 days of surface melting they increased to 52.6 and $195.5 \mathrm{ng} \mathrm{g}^{-1}$. This suggests that surface snow melting can reduce snow albedo due to the accumulation of carbonaceous particles.
\end{abstract}

\section{INTRODUCTION}

Carbonaceous particles represent a major fraction of fine aerosols. They can be divided into organic carbon (OC) and highly polymerized elemental carbon (EC), as well as inorganic carbon, each characterized by different thermal, chemical and optical behaviors (Lavanchy and others, 1999b). EC is only emitted directly from the incomplete combustion of fossil fuels and biomass, and is also believed to be a significant climate-forcing agent (Novakov and others, 2003), probably second only to greenhouse gases in its effect on global temperature in the past century (Houghton and others, 2001). However, OC originates from a variety of processes, mainly from biogenic sources and anthropogenic sources, usually along with EC. Secondary organic carbon formation from the oxidation of hydrocarbons is another source of OC. Recently, carbonaceous particles have received increased attention because of their contribution to global warming. Greenhouse forcing has been estimated to be about $2.43 \mathrm{~W} \mathrm{~m}^{-2}$ since pre-industrial times (Houghton and others, 2001). Studies demonstrate that the climatic forcing results from anthropogenic emissions of carbonaceous aerosols, and this may substantially mask the forcing by greenhouse gases (Jacobson, 2001; Hansen, 2002; Hansen and others, 2002; Hansen and Nazarenko, 2004).
EC and OC in areas with snow and ice may play an important role in climate change. When deposited on the snow and ice cover, their high optical absorption alters the surface albedo and the radiative properties of surface cover. At higher elevations and higher latitudes of the Earth, where snow and ice are prevalent, EC and OC are more effective in reducing snow/ice albedo by absorbing more of the sunlight than does a white background of clear ice. This provides a positive feedback, i.e. warming: as glaciers and ice sheets melt, they tend to get even dirtier. Hansen and Nazarenko (2004) suggest that the effect of carbonaceous particles on snow albedo may be responsible for a quarter of the observed global warming and contributes significantly to the melting of ice around the world in most recent time.

Although important to climatic impacts and ice melting, regular measurements of carbonaceous particles from snow and ice are lacking, especially from eastern Asia. Existing documents show EC concentrations in snow and ice to be highly variable. Large concentrations of EC (up to 100$300 \mathrm{ng} \mathrm{g}^{-1}$ ) have been found in snow in heavily polluted regions of the French Alps (Sergent and others, 1993). Snow samples taken from Arctic regions (excluding Greenland) in the 1980s yielded average EC concentrations of around $25 \mathrm{ng} \mathrm{g}^{-1}$, and a range of $0-127 \mathrm{ng} \mathrm{g}^{-1}$ (Clarke and Noone, 1985). In contrast, a range of only 1.4-2.7 $\mathrm{ng} \mathrm{g}^{-1}$ (average $2 \mathrm{ng} \mathrm{g}^{-1}$ ) was found in a Greenland snow core representing 


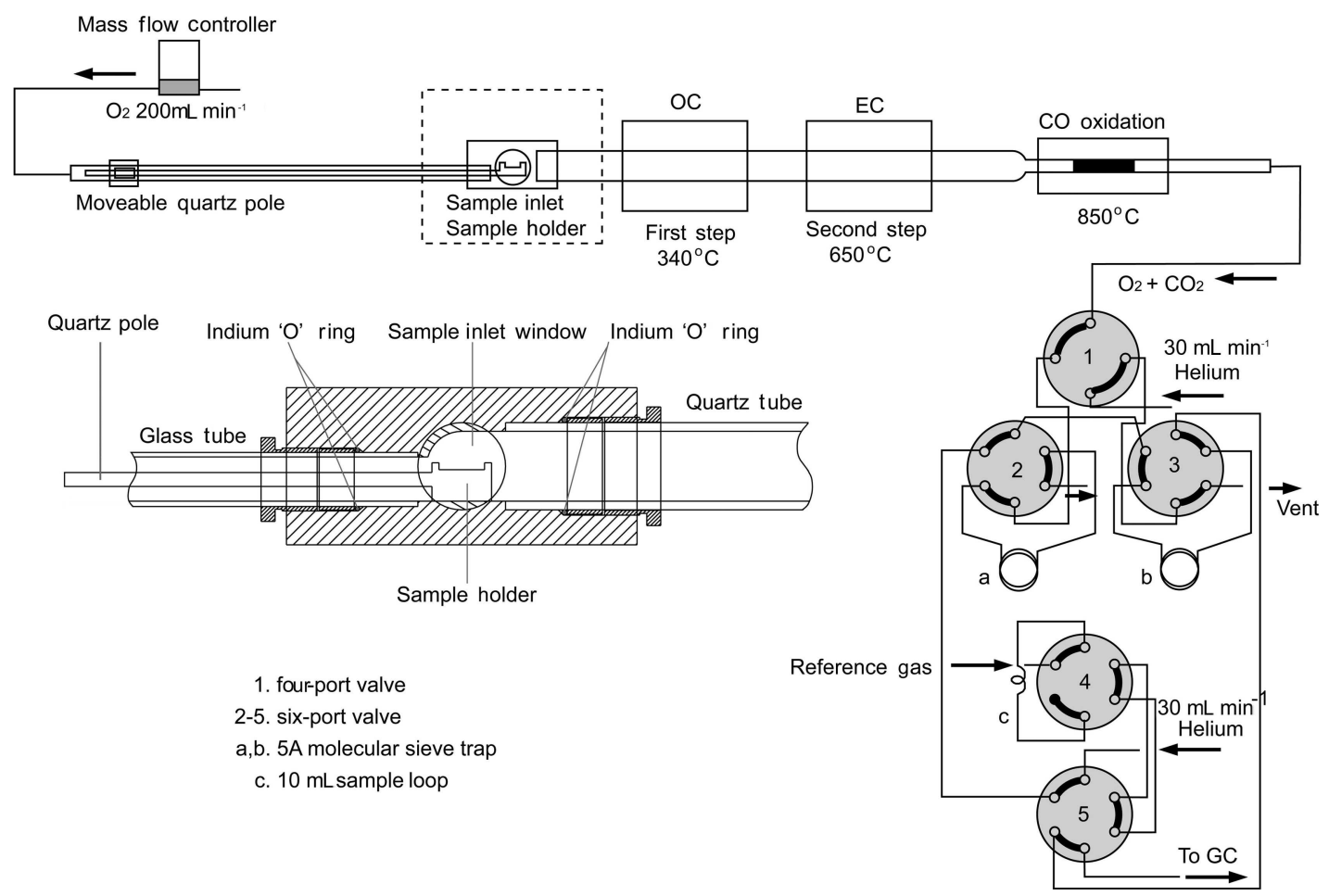

Fig. 1. Block diagram of the experimental apparatus.

the time period 1989-90 (Chýlek and others, 1995), but a later measurement yielded a range of $2-6 \mathrm{ngg}^{-1}$ (Hansen and Nazarenko, 2004). The lowest amounts of EC reported come from the relatively pristine Antarctic region. Fresh snow at the South Pole has been found to contain 0.1$0.34 \mathrm{ngg}^{-1}$ (Warren and Clarke, 1990), but $2.5 \mathrm{ngg}^{-1}$ was reported at Siple Dome above the Ross Ice Shelf (Chýlek and others, 1987).

The Tibetan Plateau is one of the largest regions of modern glaciation. There are a total of 46298 glaciers in the Chinese part of the plateau, occupying a total area of almost $60000 \mathrm{~km}^{2}$. However, the plateau is surrounded by developing countries, which are now the largest sources of carbonaceous particle emissions. Satellite images reveal a thick brown haze filled with black carbonaceous particles that abuts against the Himalaya (Ramanathan and others, 2001). The surface snow most likely contains a large amount of EC and OC, and the carbonaceous particles presumably play an important role in glacier melting, which has been accelerating in recent years. Unfortunately, no measurements of carbonaceous particles in snow and ice have previously been made in this region.

The purpose of the current research is to determine the amounts of EC and OC in snow on the glaciers on the Tibetan Plateau, for which an optimized two-step heatinggas chromatography system (THGC) has been used.

\section{EXPERIMENTAL PROCEDURES}

\subsection{Samples}

A total of 29 snow samples (from snow pits, surface snow and precipitation) were collected from seven glaciers on the Tibetan Plateau. All the collected snow samples were sealed in glass sample bottles, pre-cleaned using a liquid mixture of $\mathrm{H}_{2} \mathrm{O}-\mathrm{K}_{2} \mathrm{Cr}_{2} \mathrm{O}_{2}-\mathrm{H}_{2} \mathrm{SO}_{4}$ (25:1:46) and pure water (Milli-Q, $18 \mathrm{M} \Omega$ ). The bottles were wrapped with aluminum foil and kept frozen for future treatment. We typically collected 80$100 \mathrm{~g}$ snow samples, after allowing for the weight of the $250 \mathrm{~mL}$ sample bottles. In the laboratory, samples were weighed and then allowed to melt at room temperature in a class 100 clean room. Immediately after complete melting, the samples were filtered through quartz fiber filters (Tissuquartz 2500QAT-UP $47 \mathrm{~mm}$, Pall). The original $47 \mathrm{~mm}$ diameter filters were cut into six pieces, each $15 \mathrm{~mm}$ in diameter, and preheated in an oxygen stream for 2 hours in a tube oven at $800^{\circ} \mathrm{C}$. Filtration twice using a $316 \mathrm{~L}$ stainless-steel unit (about $400 \mathrm{~cm}^{3}$ in volume) resulted in a circular spot of about $10 \mathrm{~mm}$ diameter. The second filtration was to rinse the sample bottle and filtration unit, as well as to ensure complete transfer of carbonaceous particles to filters. Filtration efficiency was tested in several studies using similar procedures, which found efficiencies to be around 95\% (Chýlek and others, 1987; Cachier and Pertuisot, 1994; Lavanchy and others, 1999b). After filtration, the quartz fiber filters were stored in pre-cleaned glass weighing bottles and dried in glass vacuum desiccators.

\subsection{Two-step heating-gas chromatography system}

Figure 1 shows the THGC thermal apparatus used in this work for analysis of quartz filter samples. Our system is similar to that originally developed at the University of Berne, Switzerland, (Lavanchy and others, 1999a; Szidat and others, 2004) but has been modified with some different materials and detectors for our protocol. Our method involves thermal evolution of carbonaceous particles, oxidation to $\mathrm{CO}_{2}$, purge and trap, followed by reduction to $\mathrm{CH}_{4}$, as well as detection through flame ionization. The device consists of four major parts. The first part is the combustion unit composed of two tube ovens in series, through which passes an $18 \mathrm{~mm}$ ID quartz tube, where OC and $\mathrm{EC}$ are oxidized to $\mathrm{CO}_{2}$ at temperatures of $340^{\circ} \mathrm{C}$ and $650^{\circ} \mathrm{C}$, respectively, in a pure oxygen stream. A quartz rod is 
inserted in a $10 \mathrm{~mm}$ ID glass tube equipped with a quartz sample boat, which can be moved through the quartz tube by a pair of magnets. The glass tube and the quartz tube are joined in tandem by a $316 \mathrm{~L}$ stainless-steel unit with a window for filter sample loading. The second part is a catalyst oven. CO, which may be produced during sample combustion (Lavanchy and others, 1999a), is catalytically oxidized to $\mathrm{CO}_{2}$ in a bed of granular $\mathrm{CuO}_{2}$ held at $850^{\circ} \mathrm{C}$. The third part is the purge-and-trap and calibration unit, which consists of a four-port valve, four six-port valves, and two molecular sieve (5A) traps in which $\mathrm{CO}_{2}$ was absorbed. The final part (not shown in Fig. 1) is the HP 6890 Gas Chromatograph (GC) equipped with flame ionization detector (FID) and nickel catalyst system (NCS), as well as a Poropak Q packed column.

$\mathrm{OC}$ and $\mathrm{EC}$ transform into $\mathrm{CO}_{2}$ in a stream of oxygen $\left(200 \mathrm{~mL} \mathrm{~min}^{-1}\right)$ at $340^{\circ} \mathrm{C}$ and $650^{\circ} \mathrm{C}$, respectively, in our THGC. The filter sample is placed first in the low-temperature quartz oven for $40 \mathrm{~min}$, and then in the higher-temperature zone for $30 \mathrm{~min}$. In this process, OC and EC will be oxidized completely to $\mathrm{CO}_{2}$ (Lavanchy and others, 1999a; Szidat and others, 2004). Before the OC is oxidized, the sample is placed in the $650^{\circ} \mathrm{C}$ oven for $1 \mathrm{~min}$ flash heating, as suggested by Lavanchy and others (1999a). This flash heating has the advantage of minimizing pre-combustion charring (Cadle and Groblicki, 1982), since it reduces pyrolysis of OC, which could otherwise result in a positive artifact for EC (Lavanchy and others, 1999a). The resulting $\mathrm{CO}_{2}$ fractions are absorbed separately by the two molecularsieve (5A) traps at room temperature. The redundant oxygen in the traps will be removed by a helium stream for $5 \mathrm{~min}$, and then the $\mathrm{CO}_{2}$ can be injected into the GC packed column for farther separating by quickly heating the traps to $200^{\circ} \mathrm{C}$, and reduced to methane in the NCS for quantification with a built-in FID that was calibrated using an external carbon standard.

The background (mainly caused by impurities in the oxygen stream) and accuracy are dominated by the variability of the blank loads of the pre-cleaned filters, which are $0.50 \pm 0.04(1 \sigma) \mu \mathrm{gC}$ for OC and $0.38 \pm 0.04(1 \sigma) \mu \mathrm{gC}$ for EC, based on a large number of blank tests performed each day. Snow and ice sample measurements by the system are expected to give the same precision as for blank tests. A daily calibration is performed by injecting a known volume of $\mathrm{CO}_{2}$ standard gas into the GC through a six-port valve equipped with a $10 \mathrm{~mL}$ sample loop, which is pre-evacuated by a vacuum system. The standard gas volume of each calibration injection is determined and controlled by the pressure in the sample loop measured with a capacitive pressure sensor. According to the content of carbonaceous particles deposited on the filter, two levels of $\mathrm{CO}_{2}$ standards were used, 1000 ppmv and 3030 ppmv.

Carbonate is a common ingredient in snow and ice from the Tibetan Plateau. To avoid possible positive EC artifacts, carbonates were removed prior to thermal analysis by pipetting $50 \mu \mathrm{L}$ of $0.1 \mathrm{M} \mathrm{HCl}$ three times onto the sample spot (Lavanchy and others, 1999b).

\section{RESULTS}

Table 1 lists information about the snow samples collected from the seven glaciers on the Tibetan Plateau and the measurement results. The following describes the carbonaceous particle content from the different glaciers.

\subsection{Northeastern Tibetan Plateau}

Our data include samples from three glaciers on the northeastern Tibetan Plateau: July 1st (Qiyi) glacier in the west of the Qilian Shan; Meikuang (Colliery) glacier in the eastern Kunlun Shan; and Dongkemadi glacier in the Tanggula mountains.

Four precipitation snow samples (collected on the glacier surface immediately after precipitation events) taken from July 1 st glacier in the summer of 2001 yielded average OC and EC concentrations of $87.5 \mathrm{ng} \mathrm{g}^{-1}$ (with a range of 40.3$122.1 \mathrm{ng} \mathrm{g}^{-1}$ ) and $6.6 \mathrm{ng} \mathrm{g}^{-1}$ (with a range of 2.0-9.2 $\mathrm{ng} \mathrm{g}^{-1}$ ), respectively. However, the $\mathrm{OC}$ and EC concentrations increased remarkably in the five surface wet-snow samples collected 2 days after the precipitation events at the same site. Mean OC levels reached $195.5 \mathrm{ng} \mathrm{g}^{-1}$ (with a range of 96.4-296.0 $\mathrm{ng} \mathrm{g}^{-1}$ ), and mean EC reached $52.6 \mathrm{ng} \mathrm{g}^{-1}$ (with a range of $29.7-75.9 \mathrm{ng} \mathrm{g}^{-1}$ ). The snowmelting evidently results in fresh snow getting dirtier, suggesting that surface snowmelting can result in reduced snow albedo due to accumulation of carbonaceous particles.

Only one surface snow sample was taken from Meikuang glacier, in the summer of 2001 at an elevation of $5200 \mathrm{~m}$, and it yielded the highest EC concentration found on the Tibetan Plateau, $446.0 \mathrm{ngg}^{-1}$, despite having only $123.9 \mathrm{ng} \mathrm{g}^{-1}$ of OC. We note, however, that the surrounding rock strata contain coal, and black particles of coal can be recognized in the snow sample.

Four samples, from depth intervals of 0-15, 15-28, 28-40 and $40-52 \mathrm{~cm}$, were taken from a snow pit on Dongkemadi glacier. We obtained mean OC and EC concentrations in the snow samples of $125.5 \mathrm{ngg}^{-1}$ (with a range of 26.8$245.6 \mathrm{ngg}^{-1}$ ) and $79.3 \mathrm{ngg}^{-1}$ (with a range of 18.2$\left.168.2 \mathrm{ng} \mathrm{g}^{-1}\right)$, respectively. The largest contributions of OC and EC were from a dirty ice layer in the depth interval 28-40 cm, where we found 245.6 and $168.2 \mathrm{ng} \mathrm{g}^{-1}$, nearly four and three times the mean in other depth intervals, respectively.

\subsection{Himalaya}

In 2001 and 2004, we investigated three glaciers along the Himalaya from the east to the west. In the eastern region, one surface snow sample was collected from Qiangyong glacier, which is one of the sources of Yangzuoyong Co. One surface snow sample was collected from Kangwure glacier, on Xixabangma in the central Himalaya. Seven surface snow samples were taken from Namunani glacier in the western Himalaya, at 50 m elevation intervals from 6080 to $5780 \mathrm{~m}$.

Measurements from Qiangyong glacier yielded OC and EC concentrations of 117.3 and $43.1 \mathrm{ng} \mathrm{g}^{-1}$. Although the OC concentration of $161.1 \mathrm{ngg}^{-1}$ found on Kangwure glacier was higher, the EC concentration was lower, $21.8 \mathrm{ng} \mathrm{g}^{-1}$. The lowest carbonaceous particle concentrations of OC and EC were found on Namunani glacier, averaging 51.2 and $4.3 \mathrm{ngg}^{-1}$ (with ranges of $12.6-117.9$ and $0.3-9.7 \mathrm{ng} \mathrm{g}^{-1}$ ), respectively.

\subsection{The southeastern Pamirs}

In the southeastern Pamirs (western Kunlun Shan), Muztagh Ata was chosen for the collection of snow samples in 2001. Six samples, from depth intervals of 0-30, 30-60, 60-90, 90-120, 120-150 and 150-180 cm, were collected from a snow pit at $6350 \mathrm{~m}$ a.s.I. OC and EC concentrations were 
Table 1. Information about snow samples collected from the seven glaciers on the Tibetan Plateau

\begin{tabular}{|c|c|c|c|c|c|c|c|c|}
\hline \multirow[t]{2}{*}{ Region } & \multirow[t]{2}{*}{ Glacier name } & \multirow[t]{2}{*}{ Location } & \multirow[t]{2}{*}{ Sample type } & \multirow[t]{2}{*}{$\begin{array}{c}\text { Number } \\
\text { of samples }\end{array}$} & \multirow{2}{*}{$\begin{array}{c}\text { Elevation of } \\
\text { sampling } \\
\text { m }\end{array}$} & \multirow[t]{2}{*}{ Description } & \multirow{2}{*}{$\begin{array}{c}\mathrm{OC} \\
\mathrm{ngg}^{-1}\end{array}$} & \multirow{2}{*}{$\begin{array}{c}\mathrm{EC} \\
\mathrm{ngg}^{-1}\end{array}$} \\
\hline & & & & & & & & \\
\hline \multirow[t]{13}{*}{ Northeastern Tibetan Plateau } & \multirow[t]{9}{*}{ July 1st } & \multirow[t]{9}{*}{$39^{\circ} 14^{\prime} \mathrm{N}, 97^{\circ} 45^{\prime} \mathrm{E}$} & \multirow{9}{*}{$\begin{array}{l}\text { Surface snow and } \\
\text { precipitation }\end{array}$} & \multirow[t]{9}{*}{9} & \multirow[t]{9}{*}{4600} & Precipitation ${ }^{*}$ & 113.0 & 6.6 \\
\hline & & & & & & & 122.1 & 9.2 \\
\hline & & & & & & & 74.7 & 8.8 \\
\hline & & & & & & & 40.3 & 2.0 \\
\hline & & & & & & Wet snow & 275.1 & 46.0 \\
\hline & & & & & & & 296.0 & 47.4 \\
\hline & & & & & & & 121.9 & 75.9 \\
\hline & & & & & & & 188.3 & 64.2 \\
\hline & & & & & & & 96.4 & 29.7 \\
\hline & Meikuang & $35^{\circ} 40^{\prime} \mathrm{N}, 94^{\circ} 11^{\prime} \mathrm{E}$ & Surface snow & 1 & 5200 & & 123.9 & 446.0 \\
\hline & \multirow[t]{3}{*}{ Dongkemadi } & \multirow[t]{3}{*}{$33^{\circ} 06^{\prime} \mathrm{N}, 92^{\circ} 05^{\prime} \mathrm{E}$} & \multirow[t]{3}{*}{ Snow pit } & \multirow[t]{3}{*}{4} & \multirow[t]{3}{*}{5600} & $0-15 \mathrm{~cm}$ & 26.8 & 18.2 \\
\hline & & & & & & $28-40 \mathrm{~cm}$ & 245.6 & 168.2 \\
\hline & & & & & & $40-52 \mathrm{~cm}$ & 162.3 & 63.8 \\
\hline \multirow[t]{9}{*}{ Himalaya } & Qiangyong & $28^{\circ} 50^{\prime} \mathrm{N}, 90^{\circ} 15^{\prime} \mathrm{E}$ & Surface snow & 1 & 5400 & & 117.3 & 43.1 \\
\hline & Kangwure & $28^{\circ} 28^{\prime} \mathrm{N}, 85^{\circ} 49^{\prime} \mathrm{E}$ & Surface snow & 1 & 6000 & & 161.1 & 21.8 \\
\hline & \multirow[t]{7}{*}{ Namunani } & \multirow[t]{7}{*}{$30^{\circ} 27^{\prime} \mathrm{N}, 81^{\circ} 16^{\prime} \mathrm{E}$} & \multirow[t]{7}{*}{ Surface snow } & \multirow[t]{7}{*}{7} & \multirow[t]{7}{*}{$6080-5780$} & $6080 \mathrm{~m}$ & 49.6 & 7.3 \\
\hline & & & & & & $6030 \mathrm{~m}$ & 28.7 & 0.3 \\
\hline & & & & & & $5980 \mathrm{~m}$ & 12.6 & 1.7 \\
\hline & & & & & & $5930 \mathrm{~m}$ & 56.1 & 1.1 \\
\hline & & & & & & $5880 \mathrm{~m}$ & 48.5 & 2.9 \\
\hline & & & & & & $5830 \mathrm{~m}$ & 117.9 & 9.7 \\
\hline & & & & & & $5780 \mathrm{~m}$ & 44.8 & 7.4 \\
\hline \multirow[t]{5}{*}{ Southeastern Pamirs } & \multirow[t]{5}{*}{ Muztagh Ata } & \multirow[t]{5}{*}{$38^{\circ} 17^{\prime} \mathrm{N}, 75^{\circ} 01^{\prime} \mathrm{E}$} & Snow pit & 6 & 6350 & $0-30 \mathrm{~cm}$ & 199.4 & 37.2 \\
\hline & & & & & & $30-60 \mathrm{~cm}$ & 24.8 & 15.7 \\
\hline & & & & & & $60-90 \mathrm{~cm}$ & 73.9 & 31.3 \\
\hline & & & & & & $90-120 \mathrm{~cm}$ & 85.0 & 29.0 \\
\hline & & & & & & $120-150 \mathrm{~cm}$ & 217.6 & 182.3 \\
\hline
\end{tabular}

${ }^{*}$ The precipitation samples were collected immediately after it snowed on the glacier surface.

measured and found to be in the ranges 24.8-217.6 and 15.7-182.3 $\mathrm{ngg}^{-1}$, respectively. Similar to Dongkemadi glacier, a visible dirty ice layer was found in the depth interval $120-150 \mathrm{~cm}$. This layer contained $217.6 \mathrm{ng} \mathrm{g}^{-1}$ of OC and $182.3 \mathrm{ngg}^{-1}$ of EC. On average, OC and EC concentrations in this snow pit were 113.2 and $52.1 \mathrm{ngg}^{-1}$, respectively.

\section{DISCUSSION}

Our preliminary investigation indicates that the Tibetan Plateau can be divided roughly into three regions, characterized by their different carbonaceous particles concentrations (Fig. 2). The highest average OC and EC concentrations of 164.4 and $64.5 \mathrm{ng} \mathrm{g}^{-1}$, respectively, were found on the northeastern Tibetan Plateau (we exclude Meikuang glacier, due to the loading of coal from the surrounding strata). The carbonaceous particle concentrations in snow have high spatial variability in the Himalaya, but display an obvious decline from east to west. Although satellite images reveal a thick brown haze filled with carbonaceous aerosol abutting against the Himalaya in northern India, it clears over the Tibetan Plateau north of the Himalaya. The Himalaya definitely act as a barrier to the smoke and pollution. This is demonstrated by our observation of low OC and EC concentrations in the snow samples from the western Himalaya. However, we expect that the pollution can be brought onto the Tibetan Plateau by the Asian monsoon. Our measurements show that the EC concentration of $43.1 \mathrm{ngg}^{-1}$ in the snow from the eastern Himalaya is of the same order as that on the northeast of the plateau. By all appearances, the Asian monsoon brings carbonaceous aerosols released by eastern and southern Asian countries to the Tibetan Plateau only from the east, bypassing the barrier of the Himalaya. Figure 2 shows the clear downward trend of snow particulate concentrations from east to west and from north to south.

The southeastern Pamirs differs from the main body of the plateau, because the Asian monsoon has a much weaker effect in this region. Hence, the pollution sources are mainly in Eurasia. Our investigation reveals that this region is more highly contaminated, the mean $\mathrm{OC}$ and EC concentrations of 113.2 and $52.1 \mathrm{ng} \mathrm{g}^{-1}$ being of the same order as those on the northeastern Tibetan Plateau, even more contaminated than the eastern Himalaya. This indicates that the upwind countries are now the main sources of carbonaceous particles emissions.

\section{CONCLUSIONS}

OC and EC in a total of 29 snow samples collected from seven glaciers on the Tibetan Plateau were measured using a two-step heating-GC system. The results give overall mean concentrations of $\mathrm{OC}$ and $\mathrm{EC}$ in snow of 116.5 and 


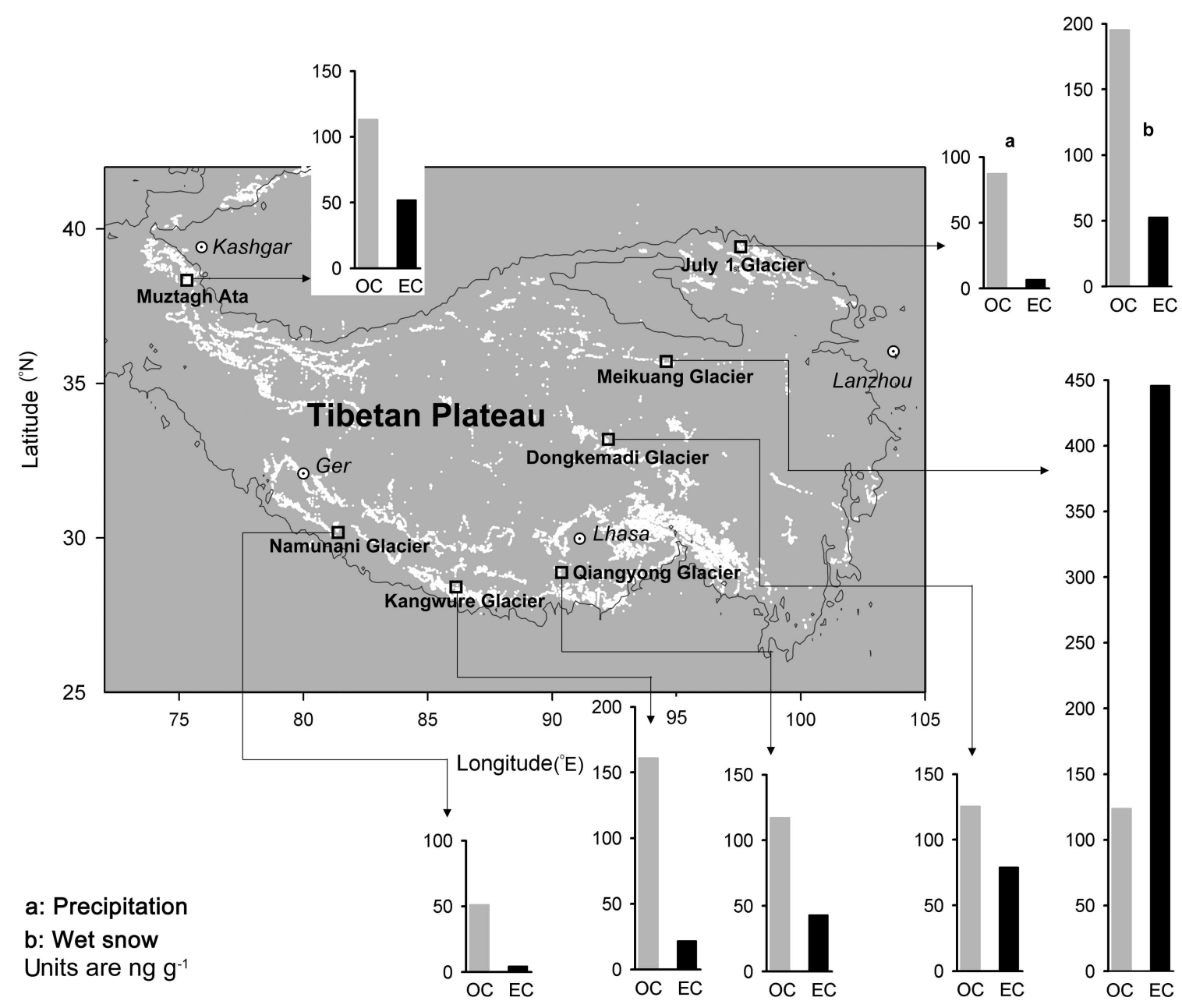

Fig. 2. Distribution of OC and EC concentrations in snow on the Tibetan Plateau.

$41.2 \mathrm{ng} \mathrm{g}^{-1}$, respectively (excluding precipitation samples and Meikuang glacier which appears to be affected by local coal deposits). The spatial pattern of concentrations shows a clear decreasing trend from east to west and from north to south (excluding the Pamirs). The highest mean EC concentration, $79.3 \mathrm{ng} \mathrm{g}^{-1}$, was found in the northeastern region, and the lowest, $4.3 \mathrm{ng} \mathrm{g}^{-1}$, in the western Himalaya. These trends demonstrate that the Himalaya act as a barrier to keep pollution on their southern side. However, the Asian monsoon can bring carbonaceous aerosols released by southeast Asian countries to the Tibetan Plateau from the east.

Snowmelting results in a marked increase of carbonaceous aerosol concentrations in snow and ice. Snow-pit samples reveal that ice layers contain higher OC and EC concentrations, and new snow will tend to get dirty after a period of melting. This establishes that surface snowmelting can result in reduced albedo due to accumulation of particles.

\section{ACKNOWLEDGEMENTS}

This work was supported by the National Natural Science Foundation of China (40471022), the Ministry of Science and Technology of China (2005CB422004, 2001CB711001) and the Innovation and Centurial Program of the Chinese Academy of Sciences (KZCX1-SW-01-10, 2004401, KZCX3SW-339).

\section{REFERENCES}

Cachier, H. and M.H. Pertuisot. 1994. Particulate carbon in Arctic ice. Analusis, 22(7), M34-M37.

Cadle, S.H. and P.J. Groblicki. 1982. An evaluation of methods for the determination of organic and elemental carbon in particulate samples. In Wolff, G.T. and R.L. Klimisch, eds. Particulate carbon: atmospheric life cycle. New York, Plenum Press, 89-109.

Chýlek, P. and 7 others. 1987. Aerosol and graphitic carbon content of snow. J. Geophys. Res., 92(D8), 9801-9809.

Chýlek, P., B. Johnson, P.A. Damiano, K.C. Taylor and P. Clement. 1995. Biomass burning record and black carbon in the GISP2 ice core. Geophys. Res. Lett., 22(2), 89-92.

Clarke, A.D. and K.J. Noone. 1985. Soot in the Arctic snowpack: a cause for perturbations in radiative transfer. Atmos. Environ., 19(12), 2045-2053.

Hansen, J.E. 2002. A brighter future. Climatic Change, 52, 435-440.

Hansen, J.E. and L. Nazarenko. 2004. Soot climate forcing via snow and ice albedos. Proc. Nat. Acad. Sci. USA, 101(2), 423-428.

Hansen, J.E. and 27 others. 2002. Climate forcings in Goddard Institute for Space Studies SI2000 simulations. J. Geophys. Res., 107(D18), 4347. (10.1029/2001JD001143.)

Houghton, J.T. and 7 others. 2001. Climate change 2001: the scientific basis. Contribution of Working Group I to the Third Assessment Report of the Intergovernmental Panel on Climate Change. Cambridge, etc., Cambridge University Press.

Jacobson, M.Z. 2001. Strong radiative heating due to the mixing state of black carbon in atmospheric aerosols. Nature, 409(6821), 695-697. 
Lavanchy, V.M.H., H.W. Gäggeler, S. Nyeki and U. Baltensperger. 1999a. Elemental carbon (EC) and black carbon (BC) measurements with a thermal method and an aethalometer at the highalpine research station Jungfraujoch. Atmos. Environ., 33(17), 2759-2769.

Lavanchy, V.M.H., H.W. Gäggeler, U. Schotterer, M. Schwikowski and U. Baltensperger. 1999b. Historical record of carbonaceous particle concentrations from a European high-alpine glacier (Colle Gnifetti, Switzerland). J. Geophys. Res., 104(D17), 21,227-21,236.

Novakov, T. and 6 others. 2003. Large historical changes of fossilfuel black carbon aerosols. Geophys. Res. Lett., 30(6), 1324. (10.1029/2002GL016345.)
Ramanathan, V., P.J. Crutzen, J.T. Kiehl and D. Rosenfeld. 2001. Aerosols, climate, and the hydrological cycle. Science, 294(5549), 2119-2124.

Sergent, C., E. Pougatch, M. Sudul and B. Bourdelles. 1993. Experimental investigation of optical snow properties. Ann. Glaciol., 17, 281-287.

Szidat, C. and 6 others. 2004. THEODORE, a two-step heating system for the EC/OC determination of radiocarbon $\left({ }^{14} \mathrm{C}\right)$ in the environment. Nucl. Instrum. Meth. Phys. Res. B 223-224, 829-836.

Warren, S.G. and A.D. Clarke. 1990. Soot in the atmosphere and snow surface of Antarctica. J. Geophys. Res., 95(D2), 1811-1816. 